Article

\title{
Active Learning Methodologies in Teacher Training for Cultural Sustainability
}

\author{
María-Pilar Molina-Torres ${ }^{1, *}$ and Raimundo Ortiz-Urbano ${ }^{2}$ \\ 1 Department of Specific Didactics, University of Córdoba, 14071 Córdoba, Spain \\ 2 Technician for the Sustainable Management of World Heritage Properties, Mosque-Cathedral, Magistral \\ González Frances Street, 21, 14003 Córdoba, Spain; raimundo_ortiz@hotmail.com \\ * Correspondence: pilar.molina@uco.es
}

Received: 5 October 2020; Accepted: 29 October 2020; Published: 30 October 2020

check for updates

\begin{abstract}
Within the framework of sustainable development, the concept of cultural heritage is linked to the heritage awareness of a specific spatial context, and to the conservation of collective memory. Despite the clear interest in cultural sustainability, the lack of research devoted to interpreting different teaching methods for transmitting patrimonial assets and preserving natural heritage is noteworthy. For this reason, the present study takes various scientific contributions as the background for considering sustainable education as a fundamental instrument to recover and conserve heritage resources, both from an informative and educational point of view. The aim of this study was to assess the training of new teachers in terms of the particular skills needed to develop active learning methods related to the teaching of heritage sustainability. The research sample consisted of 488 students in the Degree in Primary Education program. The methodology combined both qualitative and quantitative techniques, to obtain information from both observation and an opinion survey given to the students. The results show several opinions related to achieving and facilitating the implementation of innovative methodologies, due to a lack of initial university training. Generally speaking, this work provided an opportunity for students to analyze a series of prejudices regarding their working methods, and to overcome excessive theorization in their university studies.
\end{abstract}

Keywords: educational innovation; social sciences; competences; sustainability education; active methodology; heritage; teacher training; university education

\section{Introduction}

Currently, curricular proposals do not include sustainability among those teaching skills intended to be achieved by university teachers [1]. Moreover, education for sustainability is not a reality in university classrooms in Spain. Universities have a responsibility to train future teachers and to integrate sustainable culture into training processes as an essential factor in promoting education for sustainability among teachers, as well as in the citizenship they will form [2].

Our proposal relates to the educational methods that future professionals in the teaching of historical heritage and sustainable culture should implement in their primary education sessions. At the time of implementing this research proposal, the didactic models potentially chosen by the university students of the Degree in Primary Education, and the autonomy they acquire during their training, have been both taken into account in order to give priority to educational competencies over theoretical content.

In this regard, Thomas [3] pointed out that, in order to achieve these changes and be able to implement them in the educational field, participation at the community level is necessary to promote sustainability and social responsibility. In fact, two key ideas—global citizenship and volunteerism—are part of education on sustainability. The current trend is to distinguish between the terms "culture" and 
"sustainability", which are interrelated and subject to political, social, and scientific processes, and which, in any case, are difficult to clearly define [4].

This situation has led to the current state of research over the last two decades, which has resulted in numerous papers in this area [5-12]. According to Barth, Godemann, Rieckmann, and Stoltenberg, little attention has been paid to the development of key competencies related to sustainability so far [5]. For this reason, this study deals with both the conservation of cultural heritage and the development of key competencies in sustainability, through the learning methodologies. In addition, it adopted participatory research approaches and new perspectives on social sustainability. For Tweed and Sutherland, sustainability in urban environments tends to focus on technical issues, as well as on the broad contribution it can make to a sustainable urban development [6]. Additionally, other authors have validated these opinions and contributed to describing a sustainable urban environment both visually and culturally $[8,10]$. In particular, a review of these studies showed the importance of educating people on the value of urban heritage and its integration into sustainable development-hence the need for the present study.

Currently, more value is given to monumental elements in relation to historical events, without giving much importance to the natural elements that shaped the landscape of the area-which are also a sign of cultural identity. As a discipline, sustainable education blends in with the environment to raise popular awareness about nature conservation. However, identifying the term "environment" only with natural spaces is only a partial view if we do not associate it with a delimited social environment and a particular historical reality. Previous studies showed some disadvantages around cultural sustainability and heritage conservation, as two concepts that come together in a society which is both global and unequal from a local point of view [13].

The opportunities and setbacks attributed to this relationship have been researched in depth. Nowadays, this same society is immersed in a series of challenges involving advances in the economy, the environment, and the culture of sustainable development [14]. However, although the relationship between the individual and the society is progressively changing, sustainable human development acts as an indicator linked not only to economic growth, but also to social, cultural, and environmental growth.

To that end, one of the challenges a university faces is incorporating sustainability into the higher education curriculum as a fundamental component of the training of future professionals [15]. Initial training needs to be improved from its basic levels, so as to direct it towards professional practice and access to the teaching profession [16]. In this regard, the didactic training of teachers in teaching methods is an opportunity for teacher learning and a better implementation of these methods in their career development [17]. Nowadays, cultural sustainability and historical heritage are not associated with each other in the curricula, appearing separately and without relating the concepts and theories that define them.

In the same vein, it must be noted that this methodological approach must be backed up by strategies which favor the search for solutions to problems experienced in the real world. As a result of this research of a social nature, a quest for answers arises, and attitudes that promote citizen competencies are encouraged [18]. From this perspective, sustainability should be understood as the balance and long-term maintenance of both natural and cultural resources and processes in a particular territory. Hence the acquisition of citizenship skills at university allows for the conservation of the environment, as well as a sense of belonging to the environmental culture [19]. Thus, education for sustainability involves a three-pronged approach of environmental education, education in social sciences, and citizenship education [20].

Likewise, the area of civic and cultural education has reached a prominent position. Citizen's training results in education in values, along with sustainable human development. For this purpose, students learn and implement their professional skills in university practice through a real educational context. In this way, the specification of curricular elements in the classroom will inspire new ways of 
thinking among future educators [21,22]. In fact, teachers have to face several challenges which reflect the poor sustainability culture they receive at university.

Among these, it is worth mentioning the implementation of traditional methodologies, together with the conceptual strain of the curriculum in undergraduate studies, as shown in Table 1. In this context, the training of these undergraduate students should be directed towards developing skills, abilities and knowledge that will guarantee progress in their practical application of methodological strategies [23]. This is a matter of undertaking a change in the teaching methodology that focuses on the student's learning process, in an educational context which extends throughout their whole study life [24].

Table 1. From the traditional model to the active-participatory method.

\begin{tabular}{ll}
\multicolumn{1}{c}{ Traditional Method } & \multicolumn{1}{c}{ Active-Participatory Method } \\
\hline -Passive and receptive students. & -Active, constructive and critical students. \\
-Individual and lone work. & -Group and motivational work. \\
-Transmissive teachers. & -Teacher as guide and counselor. \\
-Individualism of the teaching staff. & -Coordination of teaching teams. \\
-Assessment limited to the final result. & -Assessment of the process as an end in itself. \\
\hline
\end{tabular}

Source: Drawn up by the authors.

Thus, heritage education does not seek to train experts in a particular subject—on the contrary, the goal is to awaken curiosity and a sense of belonging to a place, based on the knowledge of its closest references, so as to make use of them in a sustainable way [25]. This view allows us to understand and explain the value of heritage elements as references of the community's memory (symbolic-identity dimension), overcoming its material considerations (historical-artistic dimension). It is here where active learning methodologies in primary education promote new methodological strategies based on the implementation of different teaching styles, such as project-based learning, cooperative work, and a flipped classroom, that allow us to work in a cohesive way on heritage, historical, and cultural sustainability.

Therefore, the primary goal of this research was the compilation of methodological strategies used to develop competencies in sustainability and heritage commitment. The following specific objectives are also included to achieve this main goal: (1) promote models of sustainable practices; (2) facilitate the combination of research and teaching; (3) investigate the academic difficulties that students face in recognizing the content of cultural sustainability in teaching; and finally (4) analyze the didactic resources so as to implement an active methodology.

\section{Materials and Methods}

\subsection{Participants and Sample}

The study population ( $\mathrm{N}=488$ ) was made up of students in the second cycle of the Degree in Primary Education. Two groups were taking the subject "Didactics of the Environment" in their fourth year $(\mathrm{N}=123 ; 25.2 \%)$ at the University of Córdoba, and six groups were taking the subject "Didactics of Social Sciences" in their third year ( $\mathrm{N}=365 ; 74.8 \%$ - -specifically, 134 students at the University of Cádiz and 231 at the University of Cordoba were included. The average age of the students who participated in this research was 22.

The selection of the sample was not of a probabilistic nature: we selected participants from among groups of participants whose teachers-who were in charge of the abovementioned subjects-had been directly involved in educational research. Another aspect that stands out in this study is the competencies and curricular differences the subjects had, as shown in Table 2. It should also be noted that, although the number of students in Didactics of the Environment was lower, the representativeness of the groups was similar. 
Table 2. Specific competences of both subjects.

\begin{tabular}{|c|c|}
\hline $\begin{array}{c}\text { Specific Competences of the Subject "Didactics of } \\
\text { the Environment" }\end{array}$ & $\begin{array}{c}\text { Specific Competences of the Subject "Didactics of } \\
\text { the Social Sciences" }\end{array}$ \\
\hline $\begin{array}{l}\text {-Value individual and collective responsibility in the } \\
\text { achievement of a sustainable future and acquire the } \\
\text { necessary skills for the promotion of a healthy life. } \\
\text {-Build an updated vision of the natural and } \\
\text { social world. } \\
\text {-Know the school curricula of these sciences. } \\
\text {-Recognize the mutual influence among science, } \\
\text { society and technology, as well as the relevant citizen } \\
\text { behaviors, in order to ensure a sustainable future. }\end{array}$ & $\begin{array}{l}\text {-Appreciate culture and knowledge, as well as to } \\
\text { maintain a critical and autonomous relationship with } \\
\text { respect to knowledge, values and public and private } \\
\text { social institutions. } \\
\text {-Reflect on classroom practices to innovate and } \\
\text { improve teaching. } \\
\text {-Design, plan and evaluate both the teaching and the } \\
\text { learning processes, not only individually, but also in } \\
\text { collaboration with other teachers and professionals in } \\
\text { the center. } \\
\text {-Integrate the historical and geographical study from } \\
\text { an instructive and cultural point of view. }\end{array}$ \\
\hline
\end{tabular}

Source: drawn up by the authors.

\subsection{Design of the Investigation}

A cross-sectional design was used-it was fundamentally descriptive and interpretative, typical of qualitative research that applies non-numerical data collection and analysis. In addition, it was complemented by a non-experimental, survey-based, quantitative design. To this end, a battery of closed questions was drawn up, in order to analyze the methodological and professional training students acquire in the theoretical and practical sessions of the Degree in Primary Education [26,27]. This type of study is common in research related to the field of education, since it would respond to the amount of learning acquired, together with the evaluation of different professional skills. This methodology has allowed us to collect wide-ranging information on the topics we have worked on.

\subsection{Data Collection and Analysis Instrument}

Data were collected through direct observation of the students and through use of a survey, for them to reflect on their initial training in sustainable culture and active teaching methods. The survey was distributed before and after the training, in order to check the degree of knowledge they had gained. This kind of study is very common in educational research, as it can be applied to multiple issues whilst ensuring the validity of the sample [28]. Participants were informed that data collection was part of a study, and their responses were voluntary and anonymous. The research was carried out over three weeks in three practice sessions, lasting one and a half hours each.

The observation system resulted in a class diary which served as a narrative instrument to reflect upon their assessments, hypotheses, and conclusions [29]. We also created Table 3, which consists of several sections grouped in categories, topics and questions, for participants to express their ideas openly. Likewise, the opinions expressed by the students about both subjects-dealing with concepts such as "sustainable", "urban/rural environment", "heritage", and "empathy"—were analyzed through a qualitative evaluation.

We also created Table 4-an overview of the training activities that articulate teaching and learning-using a Likert rating scale of five values ranging from 1 (Strongly Disagree) to 5 (Strongly Agree). Our goal was to respond to the objectives and students' assessments of the different teaching methods in their university studies. In addition, regarding both the design of the survey and data processing, some key questions were defined to identify priority issues. This tool was called "perceptions and beliefs on cultural sustainability and active learning methodologies" and made use of a Likert scale (1-5) (see Appendix A), divided into two sections. Five experts from different Spanish universities took part in its validation. Once both its structure and content were approved, this instrument was delivered before starting the project (pre-test). After finishing it (post-test), the tool was complemented with pre-tests and post-tests to assess the students' opinions on the methodological 
teaching at the university, as shown in Table 5. Finally, in the analysis and interpretation of the information, an Excel spreadsheet was used as technical support, so as to make the required graphs and calculations.

Table 3. Categories on sustainability and heritage terms.

\begin{tabular}{|c|c|c|}
\hline Topic & Category & Questions \\
\hline \multirow{2}{*}{ Sustainability } & Relationship & $\begin{array}{l}\text { 1. Relationship between culture and } \\
\text { sustainable development. }\end{array}$ \\
\hline & Environmental education & $\begin{array}{l}\text { 2. Responsible management of natural areas in our } \\
\text { city (Sotos de la Albolafia, Guadalquivir River). }\end{array}$ \\
\hline Urban/rural environment & Description of a place & 3. Features of an urbanized/ruralized context. \\
\hline Heritage & $\begin{array}{l}\text { Preservation and } \\
\text { conservation }\end{array}$ & $\begin{array}{l}\text { 4. Historical relevance of the structures and } \\
\text { monuments in our city (Mosque-Cathedral and the } \\
\text { urban environment of the religious space). }\end{array}$ \\
\hline Empathy & Historical Narratives & $\begin{array}{l}\text { 5. Causes and consequences of the geographical and } \\
\text { historical location of cultural property of the past. }\end{array}$ \\
\hline
\end{tabular}

Source: Drawn up by the authors.

Table 4. Most common learning methods in the study subjects.

\begin{tabular}{|c|c|c|c|c|c|}
\hline Items & & & & & \\
\hline Master class & 1 & 2 & 3 & 4 & 5 \\
\hline Practical Seminar & 1 & 2 & 3 & 4 & 5 \\
\hline Didactic workshop & 1 & 2 & 3 & 4 & 5 \\
\hline Teaching practice (university) & 1 & 2 & 3 & 4 & 5 \\
\hline Teaching practice (classroom situation) & 1 & 2 & 3 & 4 & 5 \\
\hline Tutorial sessions & 1 & 2 & 3 & 4 & 5 \\
\hline Synthesis work & 1 & 2 & 3 & 4 & 5 \\
\hline Research work & 1 & 2 & 3 & 4 & 5 \\
\hline Project design & 1 & 2 & 3 & 4 & 5 \\
\hline Cooperative work & 1 & 2 & 3 & 4 & 5 \\
\hline Autonomous work & 1 & 2 & 3 & 4 & 5 \\
\hline Case studies & 1 & 2 & 3 & 4 & 5 \\
\hline Problem \& task solving & 1 & 2 & 3 & 4 & 5 \\
\hline Lecture-based methodology & 1 & 2 & 3 & 4 & 5 \\
\hline Research methodology & 1 & 2 & 3 & 4 & 5 \\
\hline
\end{tabular}

Source: Drawn up by the authors. 
Table 5. Opinions of the students regarding historical and heritage education $(\mathrm{N}=488)$.

\begin{tabular}{|c|c|c|c|c|}
\hline \multirow{2}{*}{ Items } & \multicolumn{2}{|c|}{ Pre-Test } & \multicolumn{2}{|c|}{ Post-Test } \\
\hline & $\mathbf{M}$ & sd & $\mathbf{M}$ & sd \\
\hline Learning historical content. & 4.03 & 1.11 & 3.37 & 1.13 \\
\hline Knowing the design of educational itineraries. & 3.08 & 1.32 & 3.88 & 1.19 \\
\hline Promoting a participative attitude. & 4.07 & 1.05 & 4.16 & 1.2 \\
\hline $\begin{array}{c}\text { Building history from an interdisciplinary } \\
\text { perspective. }\end{array}$ & 3.24 & 1.28 & 4.02 & 1.01 \\
\hline $\begin{array}{c}\text { Acquiring values of respect for the historical and } \\
\text { natural heritage. }\end{array}$ & 3.74 & 1.13 & 3.78 & 1.19 \\
\hline Promoting cooperative work. & 3.41 & 0.99 & 3.83 & 1.44 \\
\hline $\begin{array}{c}\text { Interpreting historical events and their relationship } \\
\text { with the present times. }\end{array}$ & 4.07 & 1.25 & 3.97 & 1.41 \\
\hline $\begin{array}{l}\text { Understanding environmental concepts and their } \\
\text { relation with heritage. }\end{array}$ & 4.21 & 1.06 & 4.1 & 1.22 \\
\hline Promoting reflective and civic thinking. & 3.12 & 1.33 & 3.87 & 1.15 \\
\hline Evaluating teaching-learning processes. & 4.41 & 1 & 4.46 & 0.89 \\
\hline
\end{tabular}

Source: Drawn up by the authors.

\section{Results}

The most significant results are from information gathered from direct observations and the narratives collected in the journals. The most outstanding themes focused on the methodologies used in the theoretical and practical sessions of the university. The students stated the following: "Many of the methods implemented by the teaching staff are not useful for our training as teachers".

These results also show the impact and implementation of a learning method in a sustainable education subject and heritage culture, where less innovative educational resources are used and which, consequently, are closer to the style of a master class, with taking notes as the learning tool. In line with this, the following was stated: "The sessions of the subjects are monotonous and focus on taking notes"; "It is standard practice to learn the characteristics of the more traditional methodologies".

In fact, when competence-based training was mentioned, they pointed out that "competence-based work is not covered in our practical sessions at the university". They added that "the content is not motivating in terms of the way it is explained by the teacher". They made clear, with their reflections, that the teaching methods used in their university training do not enrich their future as professional teachers. Similarly, when they talk about their experiences with the most active learning methods, they point out: "Active learning methodologies are not explained in these subjects". In this context, they say the following: "We know about some of the most innovative teaching tools and resources because we have dealt with them in other subjects".

In this context, it is now clear that the training of future teachers does not reflect a procedure focused on experimentation with practical issues based on real situations, but rather reflects a particularly theoretical approach. For this reason, the students demand the following: "We would like to learn what project-based learning (PBL) or more active methodologies consist of". It is certain that the opportunity to acquire more innovative knowledge about methodology leads to the development of professional skills from the university period onwards.

To these contributions, we must add the following: "Our teacher does not use historical or natural heritage to teach about sustainable development." This would indicate a lack of interest on the part of the teaching staff around including examples of curricular sustainability. Finally: "The use of ICTs should be directed towards the search for-and analysis of - historical and sustainable 
resources"; and also: "Digital tools provide new, up-to-date knowledge to discover economic, social, and environmental problems".

In terms of the categories related to terms and expressions such as "sustainable", "urban/rural environment", "heritage", and "empathy", opinions were based upon their personal learning experiences. The answers to each of the questions accurately described the relationship between sustainable culture and development. In practice, they were interested in expressing their doubts about both expressions: "I don't understand the relationship between sustainable culture and sustainable development, as well as the meaning of both concepts"; "I think that sustainable development and sustainable culture are not related, they are different concepts".

However, it is clear that knowledge about environmental education is not completely absent. The students think about the responsible management of the natural areas of our city, such as the Sotos de la Albolafia and the conservation of the Guadalquivir River. In fact, they wondered: "Are these two natural areas protected?"; "Who conserves them legally?"; "Do the current regulations preserve these natural monuments?"

On the other hand, the interpretations about urban and rural locations of the city were specific and partial. They highlighted the following: "To me, the difference between an urban and a rural environment is that the former is inhabited by humans, whereas the latter is not". To which they added discreetly: "I'm not quite sure ... but I think 'urban' would be a city, and 'rural' would be a field or land where no one has to live".

In terms of the issues raised in relation to historical heritage and empathy, the opinions shared a common factor: the approach to heritage assets that they did not associate with cultural sustainability. This is how they pointed this out: "I know the environment of the Mosque-Cathedral better thanks to a didactic trip with my class group at the university". Alternatively, they indicated the following: "I think that a monument like the Mosque was placed here geographically because of its historical importance"; "I don't know the causes and consequences, but it could be because of the importance of Cordoba in history".

The answers in the qualitative evaluation show the students' difficulties in translating these concepts into practice and building them from reflection. Based on all the student contributions, it is remarkable that they were not able to link sustainability to environmental education, as well as to the heritage and cultural assets of their city. These conceptual shortcomings provide an accurate description of their lack of knowledge within their professional development. In their assessments, they emphasized the value of natural and cultural heritage, even if they did not quite understand the relationship between the topics and the categories presented to them for comment.

With regards to student assessments and the different types of teaching methodologies used in their undergraduate studies, their knowledge of more traditional methodologies was where they obtained better marks, thanks to memorizing theoretical concepts. Nonetheless, autonomous work and feedback in working groups also occupy a distinct place, although they recognized that they have made greater efforts to link theory and practice.

As Figure 1 shows, in both subjects, around 4.2 and 4.6 out of 5 of the quantitative evaluations recognized that the traditional and lecture-based methodology plays a leading role in most of their university education. At the same time, between 3.8 and 3.9 of the assessments confirmed that an active and participatory methodology favors meaningful learning. Therefore, it should be noted that the teaching methods implemented today continue to give priority to the teacher's presentation, dictating notes, and the theoretical exam. Even so, they agreed to carry out research and use digital resources to interpret heritage and natural assets.

On the other hand, as Table 5 shows, the questionnaire responses suggested that the acquisition of methodological skills and abilities linked to historical and environmental education lead to higher values in subsequent tests than in preliminary tests. In fact, the results obtained show a moderate interest in the acquisition of educational skills. The vast majority of the items obtained had a value between 3 and 4, both in the pre-test and in the post-test, being higher in the latter. The items best 
considered in both tests corresponded to item 10 (4.41 and 4.46), showing a significant degree of interest in learning the evaluation instruments of an educational project to adapt them to Primary Education. The lowest values were related to the design of didactic itineraries (3.08) in the pre-test, and the learning of historical content (3.37) in the post-test, possibly because these are topics that the students cover more frequently in their university studies.

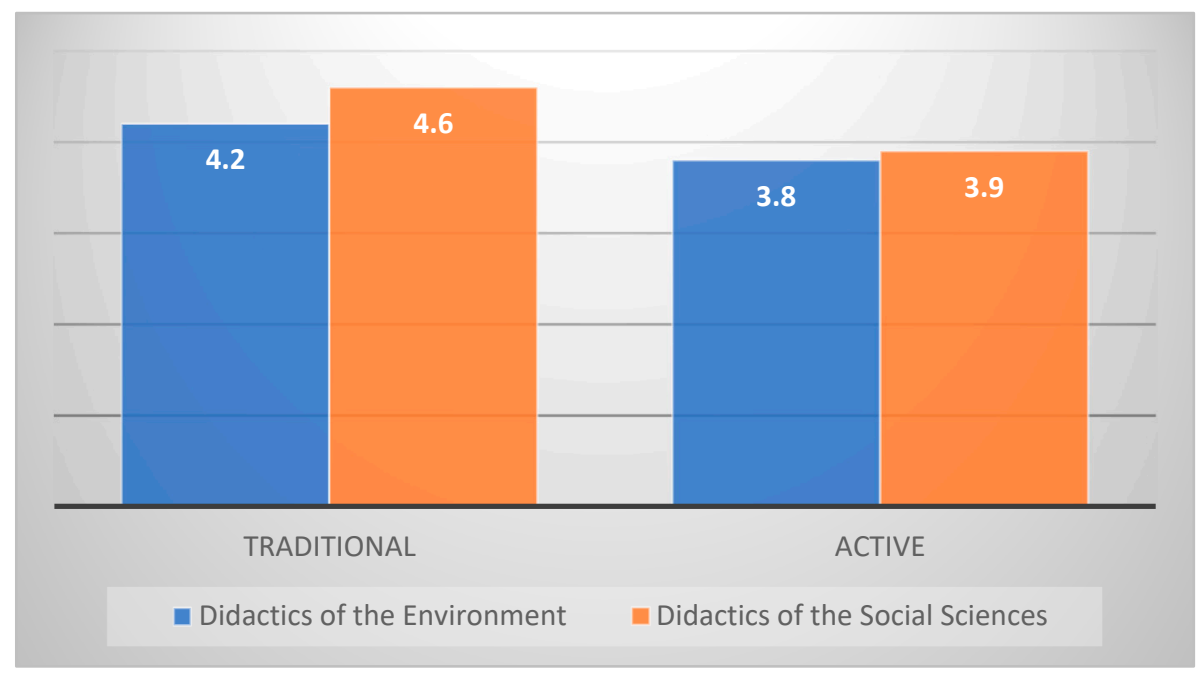

Figure 1. Comparison of students' methodological assessments according to the subject. Source: Drawn up by the authors.

Based on the coefficient of variation, the values in the post-test are more distributed, less homogeneous, and not centralized with respect to the mean, presenting more disparate values than in the pre-test. From these data, it can be verified that at the beginning of the project, the students were motivated and willing to undertake a didactic experience that they were not familiar with. However, after the implementation of the proposal, their interest decreased; we suppose that this may be due to the historical knowledge that they have of their university degrees, and the lack of practice in the development of this type of didactic proposal.

The results of the qualitative and quantitative evaluation show the difficulties of students in recognizing heritage elements and cultural sustainability. Likewise, the interpretation of environmental and historical concepts was a challenge during the evaluation due to the students' lack of prior knowledge. In the acquisition of this conceptual content, we considered the assessment of the analyzed geographic space and historical time. Thus, the qualitative and quantitative results are similar for the groups of students from both universities, despite them being engaged in different subjects. This indicates the same patrimonial and natural identity for the university students, in addition to similar degrees of interest in learning teaching methods to transmit this knowledge.

\section{Discussion}

In this study, the opinions given by the students at the Universities of Cádiz and Córdoba were an essential factor in finding out the methodological shortcomings and lack of knowledge of the didactic models used in their lessons. This has a negative impact through familiarizing students with working in a traditional way, such that they learn little about the issues of cultural sustainability. Meeting the challenge of thinking historically and sustainably lies in the training of future teachers in the university environment, in such educational stages as Primary Education.

Unfortunately, the university training assessed in this study does not delve into the most relevant aspects for the students' future teaching performance, nor does it work on the skills needed to address real classroom problems [30]. Thus, this methodological approach must be accompanied by strategies favoring the search for solutions to problems experienced in the real world, and must not be limited to 
memorizing conceptual contents in a way that makes little sense in a society where information is available at all times.

This study does have several limitations. One is related to the lack of methodological knowledge of the students' educational practices. It is a fact that the doubts of the students come from their university training and the lack of innovative teaching methods, which are scarce compared to expository methods. These static and not very novel methods have a negative impact not only on their academic knowledge, but also have a demotivating impact and practical implications for curriculum development. Regarding the strengths of the study, the students showed interest in being trained in active learning methodologies, in order to understand their closest environments and implement these methodologies in their professional futures.

Nevertheless, despite the training in citizenship and sustainability skills and their use in schools, teaching of cultural sustainability is still attached to the lecture-based learning mode and use of written tests to evaluate conceptual content. These practices do not allow us to analyze present and past events, nor to establish differences or similarities that would make cultural heritage and sustainable development a discipline which is both evolving and interesting.

Within the quantitative and qualitative evaluation investigating teacher training needs and cultural sustainability, the need to develop active learning methodologies to provide "education for sustainability" in teachers was analyzed. The literature on this subject shows that the development of an evaluation rubric to analyze generic sustainability competencies and determine the level of introduction of sustainability in teaching-learning activities is relatively limited [31].

In this paper, we discuss the different levels of achievement in terms of competencies, taking into account, on the one hand, the interests of the students in their training process [32], and, on the other hand, that not all subjects have the same level of acquisition of competencies in sustainability. This experience was also developed with students and teachers of Primary Education, who recognize the importance of citizenship skills not only in educational practices, but also in the community itself.

\section{Conclusions}

Keeping in mind the limitations of the study, we must remember that the personal views of the students are clear on the insufficient training of new teachers [33], and the problems they have in distinguishing between such concepts as sustainability and environmental education. In this regard, Moraes and De la Torre [34] stated that environmental education should be shaped as a permanent meeting space between students, teachers, and knowledge, oriented towards the common purpose of understanding citizen training.

However, there is one positive and common aspect to the views of these future primary education teachers: their affirmative responses on issues related to sustainable education and the practical impact it has on their professional training. Despite the opinions related to the learning of these topics in order to facilitate their knowledge and implementation in a classroom, doubts were raised about the function and definition of these assets. As O'Byrne, Dripps, and Nicholas [35] indicated, notwithstanding the proliferation of academic papers which propose definitions and standards for the field of sustainability and its core concepts, less research has been done to evaluate the state and curricular content of existing degree programs in terms of sustainability.

The results of this study, regarding education for sustainability, raise some questions regarding the educational practices that can be replicated in Primary Education classes [36]. It should be borne in mind that the methodological approaches the students in this study have received in their university training may favor or hinder the acquisition of a series of skills which can be useful for exchanging proposals and reflecting on teaching methods as a teacher. In this context, proposals for improvement in their personal training can support students to get involved and take charge of their own professional practices [37].

Finally, it should be noted that, from our research, in addition to meeting the objectives set, we have concluded that the difficulties students may face when exposed to an innovative and more active 
methodology depend not only on the training of their university teachers, but also on the priority given to conceptual content as opposed to educational skills [38]. Adequate initial training of new teachers translates into the acquisition of didactic elements present in the teaching-learning process, allowing them to design specific actions addressing both the causes and the consequences of education for sustainability $[39,40]$.

Author Contributions: Both authors have contributed in the same way in the realization of this work. The evaluation has been carried out by authors equally. All authors have read and agreed to the published version of the manuscript.

Funding: This research was funded by the Spanish Ministry of Science, Innovation and Universities, grant number PGC2018-097481-B-I00.

Acknowledgments: The authors gratefully acknowledge the support of the universities of Cádiz and Córdoba (Spain).

Conflicts of Interest: The authors declare no conflict of interest.

\section{Appendix A}

Scale for evaluating students' opinions: "Perceptions and beliefs on cultural sustainability and active learning methodologies".

\begin{tabular}{|c|c|c|c|c|c|c|}
\hline \multicolumn{7}{|c|}{ Training in heritage education and cultural sustainability } \\
\hline 1 & I consider that I have enough historical training. & 1 & 2 & 3 & 4 & 5 \\
\hline 2 & $\begin{array}{l}\text { I think this project can help me to think from a historical } \\
\text { point of view. }\end{array}$ & 1 & 2 & 3 & 4 & 5 \\
\hline 3 & $\begin{array}{l}\text { I would like to know more about the cultural and } \\
\text { historical sustainability of my town/city. }\end{array}$ & 1 & 2 & 3 & 4 & 5 \\
\hline 4 & Cooperative work is encouraging for me. & 1 & 2 & 3 & 4 & 5 \\
\hline 5 & $\begin{array}{l}\text { I think that a participative attitude improves education } \\
\text { on heritage. }\end{array}$ & 1 & 2 & 3 & 4 & 5 \\
\hline 6 & $\begin{array}{l}\text { I believe that interdisciplinary work benefits the } \\
\text { acquisition of content about heritage. }\end{array}$ & 1 & 2 & 3 & 4 & 5 \\
\hline 7 & $\begin{array}{l}\text { I believe that heritage awareness is essential to empathize } \\
\text { with the environment. }\end{array}$ & 1 & 2 & 3 & 4 & 5 \\
\hline 8 & $\begin{array}{l}\text { I would like to understand concepts related to both } \\
\text { history and environment. }\end{array}$ & 1 & 2 & 3 & 4 & 5 \\
\hline 9 & $\begin{array}{l}\text { I think that the interpretation of the past would help me } \\
\text { get to know the present better. }\end{array}$ & 1 & 2 & 3 & 4 & 5 \\
\hline \multicolumn{7}{|c|}{ Active teaching methods } \\
\hline 10 & $\begin{array}{l}\text { I would like to implement innovative work methods in } \\
\text { Primary classrooms. }\end{array}$ & 1 & 2 & 3 & 4 & 5 \\
\hline 11 & I believe that teaching methodologies must be active. & 1 & 2 & 3 & 4 & 5 \\
\hline 12 & $\begin{array}{l}\text { I consider that interactive teaching processes promote } \\
\text { student involvement. }\end{array}$ & 1 & 2 & 3 & 4 & 5 \\
\hline 13 & $\begin{array}{l}\text { I think that active teaching methods can help me succeed } \\
\text { in my own academic training. }\end{array}$ & 1 & 2 & 3 & 4 & 5 \\
\hline 14 & $\begin{array}{l}\text { I believe that methodological training provides essential } \\
\text { skills to teach in a classroom. }\end{array}$ & 1 & 2 & 3 & 4 & 5 \\
\hline 15 & $\begin{array}{c}\text { I think that knowing about the heritage and cultural } \\
\text { sustainability is necessary to evaluate the historical and } \\
\text { natural knowledge. }\end{array}$ & 1 & 2 & 3 & 4 & 5 \\
\hline
\end{tabular}




\section{References}

1. Cebrián, G.; Junyent, M.; Mulà, I. Competencies in Education for Sustainable Development: Emerging Teaching and Research Developments. Sustainability 2020, 12, 579. [CrossRef]

2. Albareda-Tiana, S.; Vidal-Raméntol, S.; Fernández-Morilla, M. Implementing the Sustainable Development Goals at University level. Int. J. Sustain. High. Educ. 2018, 19, 473-497. [CrossRef]

3. Thomas, I. Challenges for implementation of education for sustainable development in higher education institutions. In Routledge Handbook of Higher Education for Sustainable Development; Barth, M., Michelsen, G., Rieckmann, M., Thomas, I., Eds.; Routledge: London, UK; New York, NY, USA, 2016; pp. 56-71.

4. Soini, K.; Dessein, J. Culture-Sustainability Relation: Towards a Conceptual Framework. Sustainability 2016, 8, 167. [CrossRef]

5. Barth, M.; Godemann, J.; Rieckmann, M.; Stoltenberg, U. Developing key competencies for sustainable development in higher education. Int. J. Sustain. High. Educ. 2007, 8, 416-430. [CrossRef]

6. Tweed, C.; Sutherland, M. Built cultural heritage and sustainable urban development. Landsc. Urban Plan. 2007, 83, 62-69. [CrossRef]

7. Hong, L.; Forero, J. New Perspectives to Understand the Cultural Heritage through the Social Sustainability. In Paisaje Cultural Urbano e identidad Territorial. II Coloquio Red Internacional de Pensamiento Crítico Sobre Globalización y Patrimonio Construido; Niglio, O., Ed.; Aracne Editrice: Rome, Italy, 2012; pp. 577-588.

8. Barthel-Bouchier, D. Cultural Heritage and the Challenge of Sustainability; Left Coast Press: Walnut Creek, CA, USA, 2013.

9. Harrison, R. Heritage: Critical Approaches; Routledge: London, UK, 2013.

10. Medici, M. Sostenibilità, patrimonio e formazione. Paesaggio Urbano 2014, 5-6, 30-33.

11. Feria, J.M. Territorial Heritage and Development; Taylor \& Francis: London, UK, 2012.

12. Tilbury, D. Student Engagement and Leadership in Higher Education. In Routledge Handbook of Higher Education for Sustainable Development; Barth, M., Michelsen, G., Rieckmann, M., Thomas, I., Eds.; Routledge: London, UK; New York, NY, USA, 2016; pp. 241-260.

13. Estepa, J.; Martín, M.J. Heritage in Conflict: A Way to Educate in a Critical and Participative Citizenship. In Handbook of Research on Citizenship and Heritage Education; Delgado, E.J., Cuenca, J.M., Eds.; Information Science Reference; IGI Global: Hershey, PA, USA, 2020; pp. 43-55.

14. Ramos, T.B.; Caeiro, S.; van Hoof, B.; Lozano, R.; Huisingh, D.; Ceulemans, K. Experiences from the implementation of sustainable development in higher education institutions: Environmental Management for Sustainable Universities. J. Clean. Prod. 2015, 106, 3-10. [CrossRef]

15. Müller-Christ, G.; Sterling, S.; van Dam-Mieras, R.; Adomßent, M.; Fischer, D.; Rieckmann, M. The role of campus, curriculum, and community in higher education for sustainable development a conference report. J. Clean. Prod. 2014, 62, 134-137. [CrossRef]

16. Merritt, E.; Hale, A.; Archambault, L. Changes in Pre-Service Teachers' Values, Sense of Agency, Motivation and Consumption Practices: A Case Study of an Education for Sustainability Course. Sustainability 2019, 11, 155. [CrossRef]

17. Leal Filho, W.; Muthu, N.; Edwin, G.; Sima, M. Implementing Campus Greening Initiatives: Approaches, Methods and Perspectives; Springer International Publishing: Cham, Switzerland, 2015.

18. Molina, M.P. El Aprendizaje Basado en Proyectos (ABP) en la formación metodológica del profesorado del Grado de Educación Primaria. Enseñ. Teach. Rev. Interuniv. Didáct. 2019, 37, 123-137. [CrossRef]

19. Albareda-Tiana, S.; Alférez, A. A collaborative programme in sustainability and social responsibility. Int. J. Sustain. High. Educ. 2016, 17, 719-736. [CrossRef]

20. Parra, G.; Hansmann, R.; Hadjichambis, A.C.; Goldman, D.; Paraskeva-Hadjichambi, D.; Sund, P.; Sund, L.; Gericke, N.; Conti, D. Education for Environmental Citizenship and Education for Sustainability. In Conceptualizing Environmental Citizenship for 21st Century Education; Hadjichambis, A.C., Ed.; Springer Nature: Cham, Switzerland, 2020; pp. 149-160. [CrossRef]

21. Murga-Menoyo, M.A.; Novo, M. The Processes of Integrating Sustainability in Higher Education Curricula: A Theoretical-Practical Experience Regarding Key Competences and Their Cross-Curricular Incorporation into Degree Courses. In Transformative Approaches to Sustainable Development at Universities; Leal Filho, W., Ed.; Springer International Publishing: Cham, Switzerland, 2015; pp. 119-135. [CrossRef] 
22. Gestsdóttir, S.M.; Van Boxtel, C.; Van Drie, J. Teaching historical thinking and reasoning: Construction of an observation instrument. Br. Educ. Res. J. 2018, 44, 960-981. [CrossRef]

23. Wiek, A.; Withycombe, L.; Redman, C.L. Key competencies in sustainability: A reference framework for academic program development. Sustain. Sci. 2011, 6, 203-218. [CrossRef]

24. Fink, L.D. Creating Significant Learning Experiences: An Integrated Approach to Designing College Courses; JosseyBass: San Francisco, CA, USA, 2003.

25. Fontal, O.; Juanola, R. Heritage Education: A useful and profitable discipline within the cultural heritage management. Cadmo 2015, 17, 9-25.

26. Gómez-Carrasco, C.J.; Rodríguez-Pérez, R.A.; Mirete, A.B. Metodología didáctica y concepciones epistemológicas sobre la enseñanza de la historia. Una investigación con futuros maestros. Rev. Complut. Educ. 2018, 24, 237-250. [CrossRef]

27. Chapman, A. Taking the perspective of the other seriously? Understanding historical argument. Educar Rev. 2011, 42, 95-106. [CrossRef]

28. Sapsford, R.; Jupp, V. Data Collection and Analysis; Sage: London, UK, 2006.

29. Reis-Jorge, J. Teacher's conception of teacher-research and self-perception as enquiring practitioners. A longitudinal case study. Teach. Teach. Educ. 2007, 23, 402-417. [CrossRef]

30. Genc, M. The project-based learning approach in environmental education. Int. Res. Geogr. Environ. Educ. 2014, 24, 105-117. [CrossRef]

31. Rieckmann, M. Future-oriented higher education: Which key competencies should be fostered through university teaching and learning? Futures 2012, 44, 127-135. [CrossRef]

32. Gillies, R.M. Cooperative Learning: Review of Research and Practice. Aust. J. Teach. Educ. 2016, 41, 39-54. [CrossRef]

33. Copello, M.I.; Modzelewski, H.; Techera, D.; Fernández, J. Mirar y pensar juntos nuestras prácticas en las aulas universitarias -Narrativas docentes. In Presente y Futuro de la Docencia Universitaria: Presente e Futuro da Docencia Universitaria; Membiela, P., Cebreiros, M.I., Casado, N., Eds.; Educación Editora: Vigo, Spain, 2016; pp. 459-464.

34. Moraes, C.; De la Torre, S. Pesquisando a partir do pensamento complexo-Elementos para uma metodologia de desenvolvimento eco-sistêmico. Rev. Educ. 2006, 58, 145-172. [CrossRef]

35. O'Byrne, D.; Dripps, W.; Nicholas, K.A. Teaching and learning sustainability: An assessment of the curriculum content and structure of sustainability degree programs in higher education. Sustain. Sci. 2015, 10, 43-59. [CrossRef]

36. Poropat, A.E. A meta-analysis of adult-rated child personality and academic performance in primary education. Br. J. Educ. Psychol. 2014, 84, 239-252. [CrossRef] [PubMed]

37. Imbernón, F. En Educación, no Todo Vale. Evidencias Científicas Para Mejorar la Práctica Docente; Graó: Barcelona, Spain, 2020; Volume 5, p. 111.

38. Bleichenbacher, L.; Goullier, F.; Rossner, R.; Sura, A.S.; Andrade, A.-I.; Candelier, M.; de Carlo, M.; Diederich, C.; Kuster, W.; Vollmer, H.-J. Teacher Competences for Languages in Education: Conclusions of the Project; European Centre for Modern Languages (ECML): Graz, Austria, 2016.

39. Stubbs, M. Heritage-sustainability: Developing a methodology for the sustainable appraisal of the historic environment. Plan. Pract. Res. 2004, 19, 285-305. [CrossRef]

40. García-González, E.; Jiménez-Fontana, R.; Azcárate-Goded, P.; Cardeñoso, J.M. Inclusion of Sustainability in University Classrooms through Methodology. In Handbook of Theory and Practice of Sustainable Development in Higher Education; Springer: Berlin, Germany, 2017; pp. 3-19.

Publisher's Note: MDPI stays neutral with regard to jurisdictional claims in published maps and institutional affiliations.

(C) 2020 by the authors. Licensee MDPI, Basel, Switzerland. This article is an open access article distributed under the terms and conditions of the Creative Commons Attribution (CC BY) license (http://creativecommons.org/licenses/by/4.0/). 